\title{
Magisterium of the Church in the Face of New Interpretations of the Dogma of Original $\operatorname{Sin}^{*}$
}

\section{Introduction}

After the Second Vatican Council, theological discussions on original sin flourished ${ }^{1}$. This is surprising in that the Council itself did not discuss the doctrine of original sin, and consequently did not bring any new elements to it ${ }^{2}$. The Council confined itself to short allusions to original sin, using the traditional form of Catholic doctrine ${ }^{3}$. This does not mean, however, that this understanding of original sin has been sanctioned and confirmed anew. No theologian has attempted to interpret the Council's position in this sense. On the contrary, the fact that the Council omitted the scheme of original sin was seen as encouragement to undertake new studies of this doctrine $e^{4}$. In this omission, some

* STV 16(1978)1.

1 A relatively complete picture of these discussions, although thematically close to the issue of monogenism, is presented by T. Łukaszuk, Związek dogmatu grzechu pierworodnego z monogenizmem w katolickiej teologii ostatniej doby, Warsaw 1976. This article goes beyond monogenism and addresses all aspects of the doctrine of original sin, which have been the subject of the Magisterium. In the proposals on monogeneity, the article represents a certain correction of the position previously taken.

2 The prepared scheme De peccato originali in filiis Adae did not enter the Council at all. Cf. Paul VI's speech of 11 July 1966, AAS 58 (1966), 650.

3 Cf. J. Weismayer, "Erbsündet” und Sündenverflochtenheit in der theologischen Tradition und in den lehramtlichen Aussagen, in: Ist Adam an Allem Schuld?, Innsbruck-Wien-München 1971,360 .

4 In this sense, Cardinal G. Garrone explained the position of the Council at the International Theological Congress in Rome in 1966. Cf. Acta congressus internationalis de theologia Concilii Vaticani II, Città del Vaticano 1968, 36. 
theologians wanted to see a sign of the working of the Holy Spirit, who thus opposed the hasty "canonisation" of the traditional theology of original sin, leaving the necessary freedom for future discussion ${ }^{5}$.

The theologians found positive encouragement for their actions in Pope John XXIII's speech to the opening of the Council in which the Pope encourages us to distinguish in every dogma the proper deposit of revealed truth from the way in which this truth is expressed ${ }^{6}$. However, only the Magisterium of the Church can authoritatively interpret the content of the deposit revealed. This applies both to the writings of Bible and to the rulings of past councils. The Magisterium of the Church can - and sometimes must - indicate which theological interpretations of the contents of the faith are in harmony with the revealed doctrine and which deviate from it or distort its meaning. In order to achieve this goal, the Magisterium of the Church can use two ways: either by denouncing theological theories, even by name, as inconsistent with revealed doctrine, or by positively interpreting the content of the Catholic faith in a given point. In the latter case, it is up to the theologians themselves to confront their own opinions with the position of the Magisterium and to carry out any possible corrections. In the post-conciliar period, the Magisterium of the Church mainly uses the second way, i.e. it tries to positively submit a valid or safe doctrine of faith.

The subject of the Magisterium of the Church is not only the Pope, but - as the last Council emphasised - also bishops in communication with the Pope. Therefore, after a brief presentation of new theological interpretations of the dogma of original sin, it is appropriate to discuss the statements of both bishops and the Pope on the subject of interest to us and to assess their importance for theological research.

\section{New Theological Interpretations of the Dogma of Original Sin}

The external situation immediately after the Council seemed to be conducive to a serious discussion on the dogma of original sin. At the same time, the internal structure of this truth of faith, linked, as in no other, to the changing categories of thinking and understanding of man and the world, called for in-depth reflection in order to determine what constitutes the proper deposit of the revealed truth and what is only an adventurous expression of it. Theologians attempting

5 Cf. K.H. Weger, La théologie du péché originel en discussion, Information documentation on the United Kingdom, doss. 67-38, 2.

6 Cf. AAS 54 (1962), 792. 
a new interpretation of the dogma of original sin point to a number of reasons for this kind of work. Among these reasons, a serious position - although not the only one and not the most important - is occupied by the conspicuous inconsistency of the image of the beginnings of humanity, worked out by natural anthropology, with the image adopted so far in the traditional science of original $\sin ^{7}$. The more serious reason for the turning point in the theology of original sin can be seen in the modern progress of biblical teachings. In particular, the principle of literary genres, finally accepted by Vaticanum II, brought a great deal of light to the proper sense of revelation ${ }^{8}$. A related reason for the return of original sin in theology is the application of hermeneutical principles, worked out by biblical exegesis, to the documents of the Church's Magisterium. These principles were applied to the interpretation of Church documents from the past centuries, especially when interpreting the decree of the Council of Trent ${ }^{9}$. The abandonment of the existing philosophical and conceptual apparatus, commonly used in theology, and the creation of a new one has also had a decisive influence on the development of the doctrine of original sin in a new form. The philosophy of the previous period, and in which concepts were described as original sin, expressed thoughts in ontological categories (substance, nature, affliction, quality, etc.) and in juridical categories (head or representative of humanity, covenant, reading, etc.). Recently, instead of those concepts, categories derived from a personalistic philosophy, such as: meeting, dialogue, presence, alienation, etc. have been introduced. This set of new concepts which according to some theologians corresponds better than the previous concepts of authentic religious thought contained in the sources of faith, seriously influencing the emergence of a new form of expression revealed by the doctrine of original $\sin ^{10}$.

Two different tendencies can be observed in the attempts of Catholic theologians. The first trend was mainly aimed at aligning the Catholic doctrine of original sin with the image of the beginnings of mankind, which is now governed by the natural sciences. The discrepancy between the natural and theological view was mainly revealed in two points: on polygenism and the

7 Cf. P. Schoonenberg, Quelques remarques à propos de la discussion actuelle sur le péché originel, Information documentation sur L'Eglise conciliaire, doss. 68-4, 3. Difficulties posed to the traditional form of a lecture on original sin by natural sciences as well as changes caused by these difficulties in the theological elaboration of the problem are presented by B. Hałaczek in Antropogeneza w teologii katolickiej XX wieku, STV 13(1975)2, 47-80.

8 Cf. LG 12.

9 M. Flick, Z. Alszeghy, Il peccato originale, Brescia 1972, 24.

10 Ibid. 
attribution of the state of perfection to man at the beginning (before sin), which seemed to be decisively contradicted by natural science. The new interpretations of the dogma of original sin, which remain within the framework of the first tendency, have departed more or less decisively from both of the above two postulates of the classical doctrine of original $\sin ^{11}$. As for the abandonment of the second postulate (man's perfection before the fall), there is a certain gradation in various authors: some - denying Adam the supernatural gifts, perfecting him in the natural order, such as: knowledge, control over passions, power over nature - give him the supernatural gifts of justice and holiness together with immortality, which placed the first man high in the religious and moral order. The translation of the gift of immortality differs fundamentally from the translation used in theology to date. It is said that Adam before sin was free not from death, which is the mere end of every corporeal being, but from the painful process of dying, which in the aftermath of sin and remoteness from God has only become truly painful and dangerous ${ }^{12}$. Other theologians go even further and deny man before sin ("Adam") the real possession of supernatural gifts, holiness and justice, claiming that man possessed them at most only virtually as a promise, which would come true in the case of the non-existence of $\sin ^{13}$. These interpretations, departing from the two postulates mentioned above, also preserve all the traditional doctrine of original $\sin ^{14}$.

The second trend, much more radical, is not satisfied with the reconciliation of the Catholic doctrine of original sin with the natural sciences. That is not what it is all about in the first place. It sees in the Church's doctrine of original sin in a way of interpreting a given revelation, which is strictly conditioned by historical circumstances, and which, as only a way of expression, can be profoundly transformed. In the pursuit of these transformations this tendency does not count at all, or at least not with all the specific elements of dogma, as this dogma was formulated at the Council of Trent ${ }^{15}$. Not only is monogenism or

11 The interpretation maintained in this spirit has been presented by theologians such as: K. Rahner, Erbsünde und Evolution, Conc 3 (1967), 459-465; R. Lavocat, Réflexions d'un paléontologiste sur l'état originel de l'humanité et le péché originel, NRT 89 (1967), 582-600; P. Grelot, Réflexions sur le problème du péché originel, Tournai 1968; Z. Alszeghy, M. Flick, Il peccato originale in prospettiva evoluzionistica, Gr 47 (1966), 201-225.

12 Such a concept of the gift of immortality is presented by P. Grelot, op. cit., 87-93.

13 Cf. Z. Alszeghy, M. Flick, art. cit., 217ff.

$14 \mathrm{~K}$. Rahner makes it clear that his intention is to preserve all elements of traditional doctrine except monogenism. Cf. art. cit., 460.

15 The word "dogma" is accepted in a broad sense: as the equivalent of all Catholic doctrine on original sin, contained mainly in the decree of Trent De peccato originali. As we know, not all 
the claim of primordial human perfection invalidated but it is also believed that the claim of one numerical source of universal sinfulness does not belong to the strictly dogmatic layer of Catholic doctrine. Instead of explaining the sinful state of mankind by the sin of one man, it is explained by talking of the "sin of the world," i.e. the sum of the evil committed in the past and still being committed in the world ${ }^{16}$. In other theories of this tendency, original sin is reduced to a state of imperfection (incompleteness) which is characteristic of entities immersed in the process of evolution, aiming at continuous improvement ${ }^{17}$. Still other new theories want to understand original sin as something in demand of salvation by Jesus Christ, without any preconditions for this demanding by the crime of the individual or even by the crime of all mankind ${ }^{18}$.

Finally, some exegetes believe that what we used to call original sin is, according to the Bible's teachings, the power of present sin in the world, which man is not able to resist $\mathrm{t}^{19}$. In the latter view, the very concept of original sin as hereditary guilt becomes inadequate. There is no sin that is inherited; there is only sin that has invaded the world and spread out by human acts in history to such an extent that every human being must submit to it ${ }^{20}$.

The hallmark of the theological concepts of original sin outlined above, necessarily in a very brief summary, is that all of them - including the most radical ones - rejecting certain elements as insignificant from the doctrine of the

the sentences of this decree have the value of a strict dogmatic definition. In all contemporary discussions, it is mainly a matter of establishing what is a strictly dogmatic term in this decree, and what is only a theological explanation.

16 The author of the theory of "world sin" is P. Schoonenberg. He lectured his theory in many publications, the most important of which is: De Macht de Zonde, Melmberg 1963; French translation: L'homme et le péché, Paris 1967; German translation: Theologie der Sünde, EinsiedelnZürich-Köln 1966. In addition to Schoonberg, this theory is also accepted by H. Rondet, Le péché originel dans la tradition patristique et théologique, Paris 1967, 307-329. On the Polish ground, the theory of the "sin of the world" is upheld by Fr. Różycki, although the method of its elaboration is far from that of Western theologians. I. Różycki, Nowa interpretacja dogmatu in sensu recto: zagadnienie nieśmiertelności w stanie sprawiedliwości pierwotnej, ACr 5-6 (1973-1974), 465-508. Recently this theory has been fostered by collective work: La culpabilité fondamentale. Péché originel et anthropologie modern, P. Guilluy (ed.), Gembloux 1975.

17 Cf. A. Hulbosch, Die Schöpfung Gottes. Zur Theologie der Schöpfung, Sünde und Erlösung in evolutionistischen Weltbild, Freiburg-Basel-Wien 1965.

18 Cf. A. Vanneste, Le théologie du péché originel, RCA 22(1967), 492-513.

19 Cf. H. Haag, Biblische Schöpfungslehre und kirchliche Erbsündenlehre, Stuttgart 1967; S. Lyonnet, Das Problem der Erbsünde im Neuen Testament, SdZ 180 (1967), 33-39.

20 Cf. H. Haag, Die hartnäckige Erbsünde, “Theologische Quartalschrift” 150(1970), 456. The author demands that the term "hereditary sin" be expelled from theology (Erbsünde). 
Trent decree, represent the conviction that they preserve what constitutes its dogmatic and binding layer ${ }^{21}$. On whether this is really the case, the Magisterium of the Church proclaim these tasks include preserving (conservare), defending (defendere) and clarifying (explicare) the deposit of revealed truths ${ }^{22}$.

\section{Statements by Bishops on the Dogma of Original $\operatorname{Sin}^{23}$}

Since the proper tasks of the Church's Magisterium include both the defence of revealed truths and the interpretation of their content in relation to the current problems of the believer, both tasks must be carried out through concrete action. The statements of the bishops about original sin manifest - albeit to varying degrees - an interest in both these tasks of the Magisterium.

The care for the preservation intact of the deposit of revealed truths is marked by the letter of Cardinal A. Ottaviani, Prefect of the Congregation for the Doctrine of the Faith, from 24 July 1966 to the Presidents of the Episcopal Conference ${ }^{24}$. Among the views "which, without difficulty crossing the boundaries of a mere opinion or hypothesis, seem to violate the very dogma and foundations of faith in a certain way," the letter also includes new interpretations of the Catholic doctrine of original sin: "there is no lack of those who either treat the doctrine of the Council of Trent about original sin lightly or comment on it in such a way that Adam's original sin and the transmission of sin itself are at least dimmed" (n. 8) ${ }^{25}$. Cardinal Ottaviani saw two dangerous tendencies in the new interpretations of the Catholic doctrine of original sin: the first diminishes the very importance of the teachings of the Council of Trent, while the second exposes them in a sense inconsistent with their fundamental intention. According to Ottaviani, the importance of this science, as a dogma

21 Cf. H. Haag, op. cit., 66-71.

22 Cf. LG 25. For a theological discussion of the relevant tasks of the Church's Magisterium, see S. Mosa, Rola Kościoła w przekazywaniu objawienia, in: Kościół w świetle soboru, Poznań 1968, 45 .

${ }^{23}$ In this section we will discuss the statements of members of the Church hierarchy in which, even if they are based on the authority of the Holy See, the personal authority of the Pope is not involved.

24 Epistoła ad Venerabiles Praesules Conferentiarum Episcopalium, AAS 58 (1966), 659-661. E. Dąbrowski, Konfrontacje, Poznań 1970, 388-385.

${ }_{25}$ Nec desunt qui doctrinam Concilii Tridentini de peccato originali vel parvipendunt vel ita commentantur ut originalis culpa Adami et ipsius peccati transmissio saltem obfuscentur. AAS 58 (1966), 661 
in the strict sense, is so serious that any diminishing or disregard for it poses a threat to the very foundations of faith. No less dangerous to faith, according to Ottaviani, is the attempt to translate this doctrine in such a way that Adam's guilt and the transmission of sin itself are not clearly enough emphasised.

The Congregation's letter had a specific purpose: to inform the bishops of the ways and dangers spread here and there, so that each of the bishops could, according to his duty and office, suppress or prevent these errors. He also required bishops to discuss these matters in plenary conferences and to pass on their comments to the Holy See. The letter itself, as well as the bishops' answers, were to remain secret ${ }^{26}$. However, it happened differently. The content of the letter got into the press, often in a distorted form, causing storms in the theological environments of the West. People started to talk and write about the new Syllabus, which threatens the freedom of theological research. The Congregation for the Doctrine of the Faith therefore published the authentic text of the letter in the official organ of the Holy See in order to remove misunderstandings and exaggerated suspicions ${ }^{27}$.

From the responses of the Bishops' Conferences sent to Rome, only two were published: the response of the French Episcopate ${ }^{28}$ and the response of the Dutch Episcopate ${ }^{29}$.

The response of the French episcopate does not entirely share the concerns expressed in the letter of the Congregation for the Doctrine of the Faith. The French bishops state that the teaching of original sin is one of those truths of faith which it is difficult for many priests who are obliged to teach the faithful. They are silent because they do not know how to speak [about it]. According to the French bishops, theological work in this area is essential in order to be able to give true doctrine in an accurate, complete and comprehensible manner ${ }^{30}$.

In the response of the French bishops, the emphasis was placed on the real difficulty of the traditional doctrine of original sin, sometimes leading preachers of faith to silence. Hence the theological work that would help to overcome

26 Ibid.

$27 \quad$ Editorial note explains the motives for publishing the text. Ibid., 659.

28 Réponse de la conférence épiscopale française á la lettre circulaire de Congrégation pour la Doctrine de la Foi, DC 49 (1967) Col. 327-338 (On original sin: col. 334). E. Dąbrowski, op. cit., 383-393 (on original sin, 390).

29 Réponse des évêques hollandais au questionnaire du Cardinal Ottaviani, DC 50 (1968) col. 1096-1112 (on original sin: col. 1108-1109). The text in Dutch was published in Katholick Archief dated 2 I 1968, E. Dąbrowski, op. cit., 394-393 (on original sin, 403).

30 Cf. DC 49 (1967) col. 334. 
this difficulty, i.e. new interpretations of the Catholic doctrine of original sin are needed. These interpretations should, however, give true doctrine, in an accurate, complete and comprehensible manner. The French bishops, in the very complicated issue of the new interpretations of the dogma of original sin, confined themselves to general statements that are undoubtedly correct, but which do not contribute much to a specific doctrinal-theological situation. They said nothing about what conditions are required for the given doctrine to be a truly Catholic doctrine. Nor is there any word about when this doctrine is falsified or depleted and when it is put at risk.

Elsewhere, the French bishops write clearly that they are aware of their responsibility in the doctrinal field. "This task, we read in the document, is intrinsically positive: we must proclaim the Word of God, spread the teachings of the Council, and clearly define the established points of faith." ${ }^{31}$ Despite this general declaration, the bishops did not tempt themselves to clarify the established points of faith in the Catholic doctrine of original sin. After all, it seems that they acted in this manner, being aware of the enormous difficulties that this issue poses.

The response of the Dutch bishops shows much greater boldness in addressing the specific problems associated with the new interpretations of the dogma of original $\sin ^{32}$. First of all, it responds to the accusation made in Cardinal Ottaviani's letter that the new interpretations of original sin do not take enough account of the teachings of the Council of Trent. Dutch bishops admit that the Council of Trent preached the doctrine of original sin on the basis of its authority as a universal council. "This by no means relieves us from interpreting this Council in the light of Scripture and the whole tradition, i.e. it does not relieve us from introducing here too a distinction between the theorem and the way in which it is expressed, along with all that this distinction contains and supplements." ${ }^{33}$

It can already be seen from this statement that the Dutch bishops not only endorse the fact that the truth about original sin is expressed in a different way from that adopted at the Council of Trent but they also consider as important the two basic principles that are in force in many new interpretations of this truth of faith. The first principle states that the proper content of the teachings of the

31 Ibid.

32 This answer is assessed strictly by Dąbrowski, who believes that it contains formulations and interpretations full of insinuations and spreading anxiety and confusion. E. Dąbrowski, op. cit., 382 , note 2 .

33 Cf. DC 50 (1968) col. 1108. 
Council of Trent can only be grasped in the light of a scientific study of Scripture and tradition (including the Eastern and pre-Augustinian traditions). Only as much as Scripture and tradition say could and did the Council of Trent teach ${ }^{34}$. The second principle, commonly accepted today, demands that all decisions of the Magisterium should distinguish between the correct and deliberate theorem and the way in which it is expressed. Sometimes one attempts to identify an intentional theorem with a fundamental thought in relation to which the formal meaning of words and sentences is of secondary and insignificant importance ${ }^{35} 35$.

Turning to more specific matters, Dutch bishops stress that in the doctrine of original sin, the question of whether sin and the influence of personal sin on other people are accepted is of paramount importance. The affirmative answer to this question seems to be the most important element of the Catholic doctrine of original sin. It does not matter whether it is the sin of one man and the influence of that one sin on all. They praise the work of theologians who, on the basis of Scripture, seek to point to a more serious influence of sin as such than that of Adam himself, considered as an individual. Some theologians have thus come to a theory about the sin of the world and the inner tendency to evil of every person who is burdened with the sins of other people. This theory of the "sin of the world" is put forward by the bishops as a possible interpretation of the most important content of dogma, without claiming that it is the only or the best theory. They call for further discussion, which should highlight the benefits and drawbacks of this concept. The closure of the Dutch bishops' argument about original sin is their conviction that the Church's teaching office never defined in a way that would engage its highest authority that there was only one Adam from whom all people came.

The response of the Dutch bishops is clearly intended to show that in the modern debate on original sin, theologians cannot be accused of disregarding the decree of the Council of Trent or obscuring the idea of sin or its transmission to other people. These allegations, contained in Cardinal A. Ottaviani's letter, the Dutch bishops are trying to move away in the first place from the theories disseminated in their country ${ }^{36}$.

34 Apparently, this principle - as binding in the interpretation of the Tridentinum - was stated by H. The Hague, op. cit., 69. Cf. also: E. Gutwenger, Die Erbsünde und das Konzil von Trient, "Zeitschrift für Katholische Theologie" 89 (1967), 434-446.

35 This principle is adopted today by many theologians who interpret the doctrine of original sin in a new way. Cf. Z. Alszeghy, M. Flick, art. cit., 213ff.

36 It is worth noting that at that time, after Cardinal A. Ottaviani's letter, the famous De Nieuwe Katechismus was published, approved by Cardinal B. Alfrink, in which the theory of the "sin of the world" found itself as a catechistic lecture on the dogma of original sin. 
Nothing is known about the content of other episcopates' answers to Cardinal A. Ottaviani's letter. One can only guess that they signalled certain theories, which aroused anxiety among theologians and the faithful. The fact that Pope Paul VI recommended to the first Synod of Bishops in 1967 to deal with a doctrinal issue in the first item of his deliberations is a confirmation of this assumption. In his opening address to the Synod, Paul VI expressed the concern of the Church and his own for the preservation of the Catholic faith in its intact state and internal compactness ${ }^{37}$.

The question of new interpretations of the dogma of original sin was brought to the deliberations of the Synod in the relationship between Cardinal M. Browne ${ }^{38}$. According to the relator, this issue has become particularly sensitive today, either because of problems related to the theory of evolution, or because of the exegesis, especially in the first chapters of the Book of Genesis. These new problems encourage theologians to study the dogma of original sin to greater depth. The studies of these few elements cannot be called into question. First, original sin should not be mixed with any sum of the sins of deeds committed by people. This makes it all the more unacceptable that original sin should only be seen as a symbol of our original position, in which we were able to do both good and evil. It seems that the relationship in this negative part aims to exclude theories - though not explicitly mentioned - which original sin they would like to replace by the sin of the world or to see in it a symbol to describe the state of a certain underdevelopment of man immersed in the process of universal evolution.

In the positive part, the relator reminds us that every hypothesis must take into account: a) that we are dealing with sin truly committed at the beginning of human history; b) that by birth it is handed down to all men; c) that in every man it is inherent as its own, so that for the individual sons of the first Adam the redemption brought to them by Christ, the second Adam, is necessary. It is not difficult to notice that the positive points, which according to M. Browne should have every hypothesis faithfully reproduce the scheme of reasoning adopted in the decree of the Council of Trent. These points harmonised perfectly, especially with the monogenism assumed by this decree as certain. The other thing is whether these points belong to the basic doctrine of the Council of Trent, i.e. to those which the decree intended to pronounce in the first place.

37 Allocution à l'ouverture sollennelle du synode épiscopale, DC 49 (1967) col. 1729-1735 (mainly col. 1731).

38 Relatio de opiniontbus periculosis hodiernis necnon de atheismo, Typis Polyglottis Vaticanis 1967. E. Dąbrowski, op. cit., 418-393 (on original sin, p. 423). 
Cardinal Browne's report was not a draft resolution because his task was only to provide the synod with material for discussion on a doctrinal issue. When the discussion opened and developed his role was over ${ }^{39}$.

In the report of the doctrinal synod commission in which this issue has been discussed again, taking into account the votes of the synod fathers, there is no clear position on the new theory of original sin. The report confines itself to stating that fathers have regretted that some Catholics have questioned certain elements of faith in the mystery of original $\sin ^{40}$. It will probably not be far from the truth to say that in the Synod, following a direct confrontation between the various opinions of the fathers, there has been some general calming in the doctrinal field, including the field of original sin.

The high-profile case of the New Dutch Catechism was yet another opportunity for episcopate representatives to speak on new interpretations of the dogma of original $\sin ^{41}$. Appointed by Paul VI in the summer of 1967, the Cardinal Commission in the composition: J. Frings, J. Lefebvre, L. Joeger, E. Florit, M. Browné, Ch. Journet issued a statement in which, among other things, it responded to the Catechism's attempt to re-present the dogma of original $\sin ^{42}$. The purpose of the whole declaration was that the faithful should know how to think and testify of the Good News of human salvation, in full conformity with the Church of Christ and the See of Peter. With regard to original sin, according to the commission's statement, the new difficulties arising from the study of the origins of mankind and its slow evolution must not prevent the Catechism from faithfully presenting the Church's teaching on this subject. According to it, man, at the beginning of his history, rebelled against God, and consequently lost for himself and for all his seed the holiness and justice which he possessed; for this reason he passes on to all his descendants the true state of sin to all his seed, along with the spread of human nature ${ }^{43}$. In this statement,

\footnotetext{
39 The daily press mistakenly publicised the report by Cardinal M. Browne, seeing it as a project of a new Syllabus of errors. Cf. E. Dąbrowski, op. cit., $410 f$.

40 Relatio Commissionis Synodalis constitutae ad examen ulterius peragendum circa "Opiniones perciculosas hodiernas necnon atheismum," Typis Polyglottis Vaticanis 1967, 5.

${ }^{41}$ De Nieuwe Katechismus Geloofsverkondiging voor volwassenen, Nijmegen 1966. The Catechism aroused great interest throughout the Catholic world. Discussion of the stir caused by this catechism, cf. E. Dąbrowski, op. cit., 434-456.

42 Dichiarazione della Commissione Cardinalizia su "II Nuovo catéchisme" (De Nieuwe Katechismus), in: II Nuovo Catechismo Olandese, Torino 1969, 3-12.

43 "Le nuove difficoltà che lo studio dei problemi riguardanti l'origine del genere umano e il suo lento evolversi suscitano oggi circa la dottrina del peccato originale non devono impedire che il "Nuovo Catechismo" proponga jedélmente la dottrina della Chiesa, secondo la quale l'uomo,
} 
the commission positively highlighted the most important points of Catholic doctrine about original sin, of course in its opinion. These are: the true sin of rebellion against God committed at the beginning of mankind's history; this sin has caused a real loss of the holiness and righteousness which man really possessed before sin; man, sinful at the beginning, communicates to his descendants, together with human nature, the true state of sin. The declaration does not make it clear whether the true state of sin is simply the loss of a gift of holiness and justice, or something more. However, it seems to assume that this loss is an important element of this state.

It is worth noting that the Cardinal's commission does not include the claim that there is only one man who has sinned, especially since this one man is the natural ancestor of all mankind, among the essential points of the Church's teaching about original sin, which cannot be omitted in the catechism lecture. It also sees no need to mention man's possession of supernatural gifts, including the gift of conditional immortality, before sin - or loss of it after sin. It maintains, however, that the sin that determined the state of the hereditary flaw was committed at the beginning of the history of mankind.

In light of these points, which are considered unwavering, it is necessary to avoid, according to the following statement, expressions which may mean that original sin is only contracted by individual people to the extent that those who being inwardly included from the beginning of their lives in a society in which sin reigns will find themselves in some way in the path of sin. This negative part of the declaration undermines the teaching of the Catholic doctrine of original sin adopted by the Dutch Catechism. It is unsustainable on the grounds that it does not retain the essential points of the Church's teaching ${ }^{44}$. It cannot be denied that the statement of the Cardinal Commission is a doctrinally more mature and balanced document than the previously discussed writings of the episcopates. Nevertheless, it is difficult to accept that it, too, should express the position of all the bishops on this issue.

fin dall'inizio della sua storia, si rïbello a Dio (cf. GS, 13.22) eon la conseguenza di perdere per sé e per tutta la sua discendenza quella santità e quella giustizia nette quali era costituito, e di trasmettere a tutti i discendenti, attraverso la propagazione dell'umana natura, un vero stato di peccato." Ibid., 7.

${ }^{44}$ Based on the findings of the Catechism discussed here, the text of the Catechism has been amended in those points - including the doctrine of original sin - which has been challenged by Rome. These amendments constitute an indispensable addition (Il supplement) to all possible editions of this Catechism. Cf. G. Gozzelino, Il Supplemento al Nuovo Catéchisme Olandese, Catechesi 38(1069)8-9, 30-34. 
In order to determine the doctrinal importance of the bishops' statements, two circumstances are essential: first, these statements, with the exception of the declarations of the Cardinal Commission, are not official documents for the teaching of the faith; second, they are not compatible with each other. Both circumstances, taken together in this case, mean that the statements of the bishops discussed above have little doctrinal significance. They should be treated as an expression of the private beliefs of their authors. They were not addressed to the Lord's people as a lecture of faith, or a warning of errors, but were limited to the mutual transmission among the bishops themselves of observations about errors or dangers to the faith. The intentions of these documents did not go beyond mutual information. This also applies to the letter of the Congregation for the Doctrine of the Faith of 24 July 1966, which, according to its clear words, had a purely informative purpose. In this letter, the Congregation did not condemn any errors: it listed them only to facilitate the work of the bishops, who should, in accordance with their official responsibility, take care of the defence of faith against danger in their territory. The fact that even the publication of these documents was the work of chance is not insignificant ${ }^{45}$. Moreover, a circumstance that reduces the doctrinal significance of the bishops' statements is their divergence in content. They do not constitute a consensual testimony of faith. A testimony that is inconsistent cannot be a teaching in which the help of the Holy Spirit manifests itself, which gives the words of the bishops the character of authenticity ${ }^{46}$.

The position of the Declaration of the Cardinal Commission on the Dutch Catechism is slightly different in this respect. This declaration, intended to be published from the beginning, was intended to instruct the faithful when their faith is in accordance with the faith of the Universal Church and the See of Peter. The preservation of the Catholic doctrine points reminded in the declaration was supposed to guarantee this conformity. Given the importance of the commission as such (it acts in its own name, without referring directly to the Pope's authority) and to the objectives that guided it, it must be said that it is only theologically probable that the Catholic doctrine points listed by the commission belong to the unchanging dogmatic layer of the doctrine of faith.

\footnotetext{
45 "Huiusmodi errores et pericula, singula aquidem hic Ulic sparguntur, summaria vero synthesi collecta hac epistoła locorum Ordinariis exhibentur, ut pro suo quisque munere et officio satagat ad ea compescenda vel praecavenda.” AAS 58(1966), 661.

46 Cf. Report of the Synod Doctrinal Commission, in: E. Dąbrowski , op. cit., 431.
} 


\section{Statements by Pope Paul VI on the Dogma of Original Sin}

Pope Paul VI followed with great interest - and perhaps even anxiety - the stormy post-conciliar discussion on the dogma of original sin and the possibility of finding new forms of its expression. A manifestation of this interest was the organization, inspired by the Holy Father himself, of a symposium of a selected group of exegetes, theologians and naturalists, whose task it was to discuss the doctrinal situation in the episode of the Catholic doctrine of original $\sin ^{47}$. In his speech to the participants of the symposium, the Pope expressed the hope slightly exaggerated in his optimism - that the fruit of this meeting could be a definition of original sin better suited to the requirements of the faith and reason of the man of our times ${ }^{48}$. Paul VI pointed to the possibility of a new interpretation of the doctrine of original sin by referring to the well-known statement of John XXIII in his speech inaugurating the Second Vatican Council.

The Pope stressed that in order to develop new ways of expressing dogmatic content, theologians and exegetes need freedom of search and judgement. However, it is a question of freedom that is actually required by the scientific nature of their studies and for the good of human salvation, to which all activity in the Church should be directed. In the very nature of this freedom, there are certain limits to it: only that is allowed which serves to discover the truth - for this is what is demanded by the scientific character of studies - and what is for salvation for this is what is demanded by the subordinate and servile character of studies in the Church. The Pope made it clear that these studies are limited by the living Magisterium of the Church, which is closer to the norm of truth for all believers ${ }^{49}$.

According to the Pope, the doctrine of original sin as to its existence and universality, as well as to its nature as true sin in Adam's descendants and its sad consequences for the soul and body is the truth revealed in many places in Scripture, especially in Genesis 3:1-20 and in Romans 5:12-19 ${ }^{50}$. It is up to exegetes and theologians to have a deeper knowledge of the contents of these

47 The Symposium was held on 11 July 1966 in Rome. Its participants were: E. Dhanis, Ch. Moeler, R. Masi, R. McKenzie, P. Benoît, E. Boné, Z. Alszeghy, M. Flick, R. Gagnebet, K. Rahner, M. Labourdette, V. Marcozzi, G. Ruggieri. Cf. DC 48 (1966) col. 1346.

48 Allocutio iis qui interfuerunt Coetui v.d. "Simposio" a theologis doctisque viris habita de originali peccato, AAS 58 (1966), 652.

49 Questi limiti sono segnati dal Magisteria vivo della Chiesa, ch'è norma prossima di verità per tu tti i fedeli. Ibid., 653

50 Paul VI's attribution of the doctrine of original sin in Genesis 3.1-20 raised objections on the part of exegetes. Cf. F. Dexinger, Alttestamentliche Überlegungen zum "Erbsünde" - Problem, in: Ist Adam an Allem schuld?, op. cit., 31f. 
texts: they will achieve this knowledge if they follow the principles of analogy of faith in their research and if they follow the teachings of the Councils and documents of the Holy See. In this way they will find proper meaning in the teachings of the Church. The Pope left it to theologians to look for this meaning. Regardless of leaving theologians the possibility of searching for the essential meaning of the doctrine of the Church, the Pope pointed out that the explanations given by some contemporary authors on the question of original sin are incompatible with the doctrine of the Church. Starting from the unproven assumption of polygenism, they deny, more or less clearly, that the sin from which such a wave of misery came to mankind was first and foremost the disobedience of Adam, the "first man," committed at the beginning of history ${ }^{51}$. These explanations, according to Paul VI, are not consistent with the teaching of Scripture, tradition and the Magisterium of the Church, according to which the sin of the first man is passed on to all his descendants propagatione, non imitatione, inest unicuique proporium and is mors animae, that is a culpable lack, and not just a mere absence of holiness and justice even in new-born children. Also the theory of evolution would be unacceptable if it led to the denial of Adam's disobedience, which is decisive for the fate of mankind. This disobedience cannot be imagined as not depriving Adam of the holiness and righteousness with which he was endowed.

The Pope's objections to the natural theories of polygenism and evolutionism are not absolute. The Pope does not talk about their value in the natural sciences (he only mentions polygenism, according to the actual state of things that it is an unproven assumption), or even about their absolute inconsistency with the data of the Church's teaching. It merely points out that some theological explanations, taking into account polygenism and evolutionism, lead to the denial of the essential theorems of the dogma of original sin. This does not mean, however, that every theological interpretation that counts on polygenism or evolutionism must necessarily reject these claims.

51 “(...) inconciliabili con la genuina dottrina cattolica le spiegazioni ehe del peccato originale danno alcuni autori moderni, i quali, partendo dal presupposto, ehe non è stato dimostrato, del poligenismo, negano, più o meno chiaramente, che il peccato donde è derivata tanta colluvie di mali nell'umanità, sia stato anzitutto la disobbedienza di Adamo, "primo uomo", figura di quello futuro, commessa all'inizio délia storia." AAS 58 (1966), 654. The above statement of the Pope was interpreted differently, sometimes even contradictory by theologians. Cf. L. Lefévre, Les Leçons de l'allocution du 11 juillet 1966, La pensée catholique 21(1966)102, 32; R. Rouquette, Un discours du pape sur le péché originel, "Etudes” 10 (1966), 382; A. Dubarle, Evolution et péché originel, "Le Monde," 6 VIII 1966. 
Not without significance for the correct interpretation of the papal statement is the detail that it does not put emphasis on the individuality of the first sinner, and the use of the phrase "first man" in quotation marks the fact that papal thinking is not alien to the possibility of understanding "Adam" in a broad sense, as an expression for all "first people" 52 . Moreover, it is striking in the papal statement that it does not include in the Church's current doctrine of original sin claims of possession or loss by man of supernatural gifts, including the gift of conditional immortality ${ }^{53}$.

At the first Synod of Bishops in 1967, a thought was born, which was then transformed into a concrete proposal that the Holy See, together with the Episcopal Conferences, should develop a positive and pastoral explanation of these issues, which make up today's doctrinal problems, so that the faith of the people of God can be safely guided ${ }^{54}$. The Pope's response to this demand was a solemn confession of faith on behalf of the whole Church on June 30,1968, at the end of the year of faith ${ }^{55}$.

In this Creed, the Pope does not condemn any errors, but rather lectures positively on the doctrine of the Church, in which he should believe and actually believes God's people, and from which he must not deviate. In the case of original sin, the Creed proclaims: "We believe that all have sinned in Adam; which means that the original sin committed by him has caused the fall of human nature, common to all men, to the condition in which it bears the consequences of that sin. This state is not the one in which human nature was at the beginning with our great-grandparents, equipped with holiness and justice, and in which man was free from evil and death. Such a fallen human nature, devoid of the gift of grace that had previously decorated it, wounded in its own natural talents and subject to the power of death, is passed on to all people; in this sense, every human being is born in sin. We maintain, therefore, after the Council of Trent,

52 Commentators of the papal statement point out that the official text published in the AAS has been modified in relation to the text submitted by the Vatican press office. The original text placed some emphasis on the individual character of Adam and his role as the great-grandfather of all mankind ("...la disobbedienza di un solo primo uomo, Adamo, progenitore dell'intera stirpe umana"). This emphasis is not visible in the official text, where the phrase primo nomo is taken in quotation marks. Cf. R. Rouquette, op. cit., 382.

53 The classical theology of original sin treated the theorem of the possession by man against the sin of immortality as the dogma of faith. Cf. J. Sagües, De Deo creante et elevante. De peccatis, in: STS, vol. 2, Matriti 1958, 791-798.

$54 \quad$ Relatio Commissionis synodalis, op. cit., 13.

55 Paulus VI, Sollemnis professio fidei, AAS 60 (1968), 433-445. 
that original sin, together with human nature, is passed on by birth and not by imitation: that it is everyone's own $\sin ^{56}$.

The Catholic doctrine thus laid out, which must guide the faith of the people of God, can be summed up in the following points.

a. All men have sinned in Adam, which means that his sin has determined the fallen state of nature of all men, in which this nature bears the consequences of Adam's sin. Therefore, it is maintained as a binding doctrine about hereditary sin itself, about sin in somebody (in Adam). In comparison with the teachings of this point, all theological concepts which are difficult to maintain and which, while denying the idea of inheritance, would like to identify original sin with the inevitability of committing personal sins, turn out to be difficult to maintain. According to the teaching of Paul's Creed, original sin is a sin committed in alio; this is its specific and required content by the dogma.

b. The state in which human nature found itself in the aftermath of the sin of that other person (Adam) is not the state in which it was in man (in our great-grandparents) before sin. Man before sin was equipped with holiness and righteousness and did not know evil and death. In other words, the Church's current doctrine of original sin includes the assertion that there is a real existence of a state of primary justice in which man truly possessed grace and justice, enjoyed moral innocence and freedom from death. Theological theories, which question the real existence of a state of primary justice, are in opposition to the Church's doctrine, which is recalled at this point.

c. The inner structure of original sin identifies itself with the state of a fallen nature caused by the sin of someone else (Adam): this state is characterized by the lack of grace that had previously adorned human nature, the injury of its natural talents and the submission of nature to the power of death.

d. The original sin thus described can be passed down with human nature by birth, not by imitation, and is everyone's own sin.

56 "Credimus omnes in Adam peccavisse; quod significat originalem culpam ab illo commissam effecisse, ut natura Humana, universis hołaminibus communis, in talem laberetur statum in quo illius culpae conseąuentias pateretur. Qui status iam ille non est, in quo natura Humana initio in protoparentibus nostris, utpote in sanctitate et iustitia constituas inveniebatur, et in quo homo expers erat mali et mortis. Itaque haec humana natura sic lapsa, gratiae munere destituta, quo antea erat ornata, in ipsis suis naturalibus viribus sauciata atque mortis imperio subiecta, omnibus hominibus traditur; qua quidem ratione omnis homo nascitur in peccato. Tenemus igitur, Concilium Tridentinum secuti, peccatum originale, una cum natura humana, transfundi propagatione, non imitatione, idque inesse unicuique proprium.” AAS 60 (1968) 439. The Polish translation, disseminated as the Creed, Poznan 1971, is exceptionally incorrect. In the passus of original sin, this inaccuracy reaches the point of distorting the fundamental sense. 
The Pope, recalling the fundamental points of the Catholic doctrine of original sin, which should not be lost in theological interpretations, uses traditional terminology. He speaks of Adam, of our great-grandparents, of the sin committed by Adam as the cause of the universal state of decline. Does it intend to teach that, according to the Church's valid teaching, there was only one Adam (or one pair of great-grandparents) who is responsible for the religious-moral ruin of humanity, or that only one sin of this one Adam is the direct cause of the said ruin, or finally that this Adam is the natural forefather of all mankind? It seems that in the absence of a clear emphasis in Paul's Creed on these matters, often questioned by theologians, it can be concluded that, according to the Pope, they are not essential and necessary points of the doctrine of faith about original sin. They are the Church's accepted way of expressing the content of the faith, but they do not identify with the content itself. The doctrine of faith recalled by Paul VI, therefore, does not require that the perpetrator of our original sinfulness be necessarily the individual Adam, or that in his one-off sin we see the total cause of this sinfulness, or the individual Adam as the natural forefather of all mankind. Theological theories, which with the preservation of other binding points of Catholic doctrine depart from the idea of one ancestor of humanity in explaining original sin, limiting themselves to the idea of one sinner (theological monogenism), and even resignation from the postulate of one numerically common source of sinfulness (theological polygenism), do not collide with the Creed of the people of $\mathrm{God}^{57}$.

Pope Paul VI returned to the theme of original sin in his address to the general audience on 5 May $1971^{58}$. He states that the doctrine of original sin is very often questioned today. Thus the Holy Father reminds us of certain points of Catholic doctrine: original sin does not identify with personal sin; it is an inherited sin, both in terms of guilt and punishment, of Adam's sin; this inheritance has the following consequences: enmity with God (Ephesians 2:3), the deterioration of the balance in nature (Romans 6:20) and the loss of immortality, which was the privilege of mortal man in a state of justice.

It is easy to see that in this speech the Pope repeats in detail what he included in a solemn form in his Creed. The Holy Father's remark that the doctrine of original sin is being questioned today proves that, according to the Pope's discernment, his confession of faith has not achieved all of its purposes at this point. In the statements of the Pope discussed above, some slight shifts

57 Cf. T. Łukaszuk, op. cit., $335 f$.

58 Paul VI, Allocution de l'audience generale du 5 mai 1971, DC 53 (1971), 552. Italian text in "Osservatore Romano" of 6 V 1971. 
in emphasis can be seen in secondary matters, but in important matters they invariably present the same points of Catholic doctrine about original sin.

The Pope's statements about original sin are undoubtedly of greater doctrinal significance than the speeches of the bishops discussed earlier. Especially the papal Creed of the People of God, uttered by the Supreme Shepherd on behalf of all the people - as the official name of the Creed indicates - cannot fail to have a certain doctrinal seriousness. For a correct assessment of this seriousness, it is essential to take into account, on the one hand, the Pope's intention and, on the other hand, the nature of the act itself, which belongs more to the pastoral field than to the magisterial one in the strict sense ${ }^{59}$. The Pope's intention, clearly indicated in the introduction, was not to define new truths, but to maintain and strengthen an existing faith. This is especially evident in the section on original sin. The Pope does not make any new claims on this subject, but only upholds the teachings of the Council of Trent about original sin. It is striking that the Pope does not uphold this doctrine with all its details (Adam, the first man, one forefather of mankind, one source of universal sinfulness), expressed in the canons of the Council decree, but only reminds us of what really constitutes a subject of safe faith in this doctrine, the theological interpretations of which should not be ignored.

The solemn form of expression used by the Pope in the Credo Populi Dei seems to guarantee that the truths about original sin contained therein are still the subject of Catholic doctrine in force today. All new interpretations of original sin developed by theologians, if they wish to be Catholic interpretations, must therefore take into account the points of the Catholic doctrine of faith, as recalled and confirmed by Paul's Creed. However, does this mean that all these points are an unchangeable dogmatic science? Some theologians, suggested by the solemn form of the Creed of God's people, were inclined to assume that the Pope repeated in it only that of the Trent decree, which dogmatically defined the original state and original $\sin ^{60}$. However, the above assessment does not seem to be correct.

The Pope mentions neither in the introduction nor in the text itself that he limits himself only to a repetition of defined dogmas. It is unjustifiable to impose such an intention on him. He merely wants to confirm (confirmare) the faith

59 It seems that A. Kubiś's assessment does not take into account the pastoral character of the Creed of Paul VI and is therefore exaggerated. A. Kubiś, Kwalifikacja teologiczna wyznania wiary Pawła VI, “Analecta Cracoviensia” 1 (1969), 185-189.

60 Such an opinion was represented a few years ago by I. Różycki, Pawłowe "Credo narodu Bożego," in: WNZP, vol. 3 (1969), 140. 
of the brothers, i.e. the faith of the whole Church in the form and power that it possessed at the time of the proclamation of the Creed. The faith of the Church lives not only in dogmas, but also on the truths of Catholic doctrine, which, although contained in the documents of the Magisterium (even the solemn Magisterium), can only be theologically certain or only theologically probable. Their theological qualification can be determined by analysing the documents from which these truths originate. Applying the above principle to the doctrine of original sin, as recalled by Paul VI's Creed, one can question whether, for example, the doctrine, upheld by the Pope, of human possession before sin and the loss after sin of the gift of bodily immortality, really belongs to dogmatically defined truths. ${ }^{61}$ Even in this case, however, if it was not about dogma in the strict sense, the theologian should feel bound by the Pope's position. There is no right to reject this recklessly, since the Magisterium of the Church considered it advisable to uphold it.

\section{Conclusion}

Anyone who closely observes the relationship between the Magisterium and theology in recent years with regard to original sin feels a twofold statement being imposed: first, theologians have not ceased to preach new interpretations of the dogma of original sin even if they do not agree with everything in the postulates contained in the statements of the Magisterium of the Creed of Paul VI inclusive ${ }^{62}$; second, the Magisterium of the Church does not speak out on this matter ${ }^{63}$. These two parallel facts, constituting a certain problem, at the same time form the basis for solving it.

61 The doubt in question was put forward by I. Różycki during the symposium "reinterpretation of dogmas" in Krakow, 26-28 III 1973, in the paper entitled Nowa interpretacja dogmatu in sensu recto: zagadnienie immortality w stanie sprawiedliwości pierwotnej, published in "Analecta Cracoviensia" 5-6 (1973-1974), 465-508. The author even believes that in the present state of affairs, i.e. taking into account the Creed of Paul VI, theologians may depart from corporal immortality in the theological interpretation of the state of primary justice.

62 Cf. Z. Alszeghy, M. Flick, II decreto tridentino sul peccato originale, "Gregorianum" 52 (1971), 595-637; P. Grelot, Péché originel et rédemption, examinés a’partir de l'épître aux Romains, Paris 1973; P. Guilluy (ed.), La culpabilité fondamentale. Péché originel et antropologie moderne, Gembloux 1975.

63 Review of the Magisterium's statements from the period after 5 V 1971. (Paul VI's speech in a general audience) proves that none deal with the question of original sin. 
It must first be said that an oversimplified way of solving the problem would be to attribute to theologians, who preach new theories of original sin, a mere disobedience to the Magisterium's teaching, or a disregard for its seriousness. Such voices could be heard from those authors who attributed a onesided apologetic and adjudicating character to the speeches of the Magisterium, especially the Creed of the People of God ${ }^{64}$. Moreover, it is impossible to maintain the conviction - in the face of obvious facts to the contrary - that Western theologians accepted Paul's Creed with a pact of silence. On the other hand, it is true that the majority of theologians saw Paul VI's Creed as a pastoral address, which was equally guided by the two objectives listed by the Pope in the introduction: to affirm the faith of the brothers and to transmit its content in a form appropriate to the requirements of our times. The Pope's aim was not only to defend endangered points of Catholic doctrine, but also to present its content in a new form. Therefore, Paul VI's Creed was supposed to be an attempt, undertaken by the Master's Office, to present the unchangeable truths of faith in a new form, i.e. an attempt to reinterpret existing doctrinal formulas. According to many theologians, the realisation of this task in Credo was not the happiest ${ }^{65}$. This fact leaves room for the work of theologians, aiming at new interpretations of the truths of faith, including the dogma of original sin. Theologians working on this issue want to see in their efforts the implementation of the Pope's 1966 recommendation, in which he entrusted theology with an elaboration of a more contemporary definition of original sin, i.e. better responding to the requirements of faith and reason, which are felt and revealed by the people of our time ${ }^{66}$. 